\title{
GOD IN ALICE WALKER'S THE COLOR PURPLE; A PARADOX OF THE DIVINE
}

\author{
Nailil Muna Yusak \\ Graduate School of Global Studies \\ Doshisha University \\ Karasuma Campus Room \#209 \\ Kyoto, Japan \\ Sultan Agung Islamic University \\ Semarang, Indonesia \\ naililmuna@unissula.ac.id
}

\begin{abstract}
Over time, as secularization took root in Black churches during the Civil Rights era, the prevalent framework in understanding African American spirituality discourse has shifted from theology to sociology. This paper tries to discern this major shift from the black literature perspective. It aims to discuss the main charachers' paradoxical state of mind in understanding God in the novel The Color Purple. The 1982 Pulitzer Prize for fiction winner is organized around an intimate conversation between two female characters, Celie and Shug Avery, whose understanding of God were challanged by complexity of sexism and racism in the black family. Sociological approach is adopted to understand the characters' dynamic concept of God. Discussion in this paper suggested that Alice Walker's naturalist theology is embodied in Celie and Shug Avery's conceptualization of God in the novel.
\end{abstract}

Keywords: Black Theology, The Color Purple, God in Black Literature.

\section{INTRODUCTION}

Black literature arose out of the experience of blacks in the United States, especially with regards to historic racism and discrimination, and was an attempt to refute the dominant culture's literature and power. Beginning in the 1970s, black literature reached the mainstream as books by black writers continually achieved best-selling and award-winning status (Hoffman, 1951, p. 23). This was also the period when the works of black writers began to be accepted by academia as a legitimate genre of American literature. As part of the larger Black Arts Movement, black literature began to gain momentum in the late $20^{\text {th }}$ century America. Some of the most prominent black scholars and writers contributed in promoting and (re)defining Black literature during this 
time period, including fiction writers are; Amiri Baraka, Toni Morrison, James Emanuel and the one I am about to present; Alice Walker.

Understanding historical as well as sociological background of the black community at large is important to understand what happend to the black theology and how it affects black woman's role in black America. Darlene Hine (1997, p. 2-3) explains that when Christianity was introduced in North America to the slave community, it came with a set of rules and norms; “... slaves were often required to attend the same churches as their masters. They were given religious instructions". Around the turn of the century, black American were already tired of the discrimination they experience in the 'house of God' and started to form separate black churches. Slowly, throughout the nation, Black churches offered black community from freedom of oppression to conscious separatism with a spiritual focus on the secular, and social as well as political concerns of the black community. Following emancipation, the church continued to exist at the center of black community life.

Religion and black women have always been closely interwoven in Black America, as they were in Africa. In Black churches, they are responsible in prayer, music and testimony. Black women also served as missionaries, but their role were usually limited. Preaching, officially, was left to men (Hine, 1997 , p. 4). When secularization started to took root in Black churches during the Civil Rights era. The prevalent framework in understanding African American spirituality discourse has then shifted from theology to sociology.

I subscribe to critics Miller's notion (1965, p. xxiv) that literature is a form of consiousness. It is the act where a mind takes possession of space, time, nature or other minds. Literature may also express consciousness of the self to God. To certain extent, it can also express consciousness to God himself. This paper aims to discuss the main characters' paradoxical state of mind in understanding God in The Color Purple. The 1982 Pulitzer Prize for fiction winner is organized around an intimate conversation between two female characters, Celie and Shug Avery, whose understanding of God are challanged by complexity of sexism and racism in the black family. In addition to historical studies of the Black Americans, sociological approach is adopted to 
Yusak, God in Alice Walker's the Color Purple; A Paradox of the Divine

present an elaborative analysis to the discussion. Although other major Abrahamic religion, such as Islam, is popular in the Black theology, this study limits its discussion by focusing on Christianity with a particular attention on the doctrine of General Revelation.

\section{DISCUSSION}

God and Revelation in Black Theology

Tradionally, religious issues have always been central to literary works worldwide. Writers of all times and ages, different socio-cultural backgrounds, and various ideological leanings have made religious issues an important focus in many of their works. Religiosity has become an inseparable part within the history of black literature. One proof is that during the slavery time, it was typical for a slave autobiographer to satirize American religious institutions i.e. the Church and the practitioners, for their continued support to the enslavement of the black race in America. Frederick Douglass, for an example, has repeatedly indicted American Christianity for its double standards and hypocrisy in the face of slavery. Many other slave narrators have equally shown how the practice of slavery in America depended much on religious institutions for its survival.

The emergence of Modernism and Liberalism in America in 1920s has definitely played a major role in Black theology. Literary critics respond differently regarding this particular issue. American literary critic Hillis Miller (2000, p. 1) believes that the role of God was weakening that $\mathrm{He}$ is no longer prevalent in modern Black literature. Miller asserts (in Erickson, 2007, p. 2) that "... God, it seemed, now truly dead and modernism had sounded its dead knell". A gradual withdrawal of God from the world, he adds, is reflected in many Post-Medieval literary records. Black scholar-pastor Thabiti Anyabwile presented a slightly different perspective. Anyabwile pointed out in The Decline in American Theology; From Biblical Faith to Cultural Captivity (2007) that although God has not disappeared in Black American's life, there was a noticeable decline in Black theology. However, this paper argues that God 


\section{EduLite}

Journal of English Education, Literature, and Culture

Volume 1, Number 2, August 2016

concept is not completely absent from modern literature, especially black literature. In response to Miller's proposition, Erickson (2007, p. 3) introduces an alternative upon seeing the godlessness of modern literary work suggesting that "... God did not disappear, but inscribed and disguised within the difficulty and contradictory nature of many modernist works' structures and ideologies." Discussion on God-nature relation, as an alternative to understand the divine will be elaborated further in the next section.

I believe in CS Lewis when he argues that human-God relation is the most intimate and private relation a person could possibly have. After all, who knows a creation better than its creator? In their attempt to know the unknown, each person often develops a unique relationship which is different from one another. For centuries, study on religion has been a method in understanding a complexity of human's relation to the divine power - God, spirituality, and nature. Some longstanding questions that have been around for decades include: How does one understand God? Is studying the sacred text the only prescribed way to know God? Can one's understanding of God be different from others? Historically, Protestant Christianity resolved the problem of knowing God by considering two types of individual revelation from God: general or natural revelation and special revelation (Anyabwile, 2007, p. 24). The doctrine of general revelation held that God left his imprimatur on the design of the universe and in the conscience and moral laws of humanity. This doctrine believes that the Creator communicated something of his person and divine through the created order, including the conscience and moral laws ingrained in the individual and human society. This explains that with application of reason, the natural order reveals God in a real and true sense. Special revelation, on the other hand, answered church's need for more particular information regarding the character and plans of God, his command of people, the way of salvation. Both the Old and the New Testament, in fact, contained this doctrine of special revelation to God. Holy scripture defines and explains the attributes of God; his wisdom, holiness, mercy, love, supremacy, sovereignty, justice, etc. This doctrine offers human beings to know and relate to God with accuracy. 
Yusak, God in Alice Walker's the Color Purple; A Paradox of the Divine

Anyabwile (2007, p. 26) further contrast the two doctrines in the following manner:

Where general revelation provided awareness of the existence of God as demonstrated by his creation, special revelation particularized who this God was in his triune character, what his intentions were vis-a-vis humanity and history, and how God and humanity could be joined in meaningful relationship. The page of scripture contained this message and provided the one sure means of knowing the person and the mind of God. In these pages, God disclosed himself and crossed the epistomological chasm between his infinite existence and humanity's finite reson.

Special revelation and general/natural revelation are complementary rather than contradictory in principle. At the twilight of American realism where events and social conditions are frankly represented without idealization, depiction of the latter in black literature writings started to emerge. Central to the study of natural revelation in black theology is Bishop Daniel Alexander Payne (1811 - 1893). Many of his writings were chronicles of the feeling of enslaved Africans to the religious hypocricy of those who profess Christianity yet hold slaves (Pinn, 2009, p. 13). Bishop Payne's view of natural revelation (in Anyabwille, 2007, p. 31) explains that God can condescend or lowered himself to the level of man's ability in order to communicate with his believer. Further, he concluded that " ... if people would simply apply their minds to the study of the universe, which is suitably fashioned to fit their intellectual abilities, they may come to understand the character, eternality and power of God." For Payne, the idea that God speaks and can be heard in and through the created universe was unquestionable. In Payne's thought, not only the incommunicable attributes of God were revealed in the physical universe, but the moral laws of God were also codified into the structure of the universe. Payne's view on God and nature relations is also shared with English poet and Jesuit priest Rev. Gerard Hopkins (1844-1889) who considers nature as a remarkable medium to get to know Christ and oneself, believed that “... each natural things is also a scape of Christ. To know nature is also to know oneself for the natural world is a mirror in which a man see hints and reflections of his selfhood." And therefore, to know himself and God better, Rev. 
Hopkins believe (in Hillis, 2000: p. 317) that one should perceive himself as the scape of of the common nature and recaputulate in little all the variety of the creation, dragonflies, stones, trees, flowers - everything, for to know them is to know oneself and Christ.

Understanding God vs. men's law from a universal natual law persective suggests that human's moral agent will be governed fairly if it is based on the universal natural principle of humanity. Unlike rest of the nature, men was created with self-consciousness and freedom including freedom not to praise God and choose not to conduct righfully on Earth. Right action does not come spontaneously to man. Miller (2000, p. 328) explains this rationale as follow:

The inscapes of nature can die, but they cannot be evil, for nature is incapable of producing beautiful evil. As long as natural things exist, they do what comes naturally: kingfisher catches fire, dragonflies draw flame, and stones ring. This spontanious expression of their inner nature is their way of praising God. Such praise is unintentional, and therefore neither right or wong, merely good ... Natural things can never fall short of that degree of perfection in which thery are created.

Supporting Miller's proposal, Payne opinied (in Anyabwille, 2007, p. 312 ), "the heart of the legislator is always seen in the laws he enacts; if he be just; his laws will be just and equitable; if he be a tyrant, his laws will be unjust and tyranical." This moral law applied itself universally and indiscriminatively, favoring no particular ethnicity as human laws will most likely do. It is for this reason that religious naturalism is also refered to religious humanism. Rather than perceiving religious naturalism as the opposite of supernaturalism, this paper follows a more general definition by Jerome Stone $(2008$, p. 1) as the type of naturalism (set of beliefs and attitudes that focuses on this world), which affirms that there are religious aspects of this world which can be appreciated within a naturalistic framework. Charles Hardwick (in Stone, 2008, p.3) summarizes five implication of naturalistic outlook in religious thinking: (1) that God is personal, (2) that some form of cosmic theology is metaphysically true, and (3) that there is a cosmically comprehensive conservation of value". Religious naturalism and the role it plays in Alice Walker's concept of God will be adressed in the next section. 
Yusak, God in Alice Walker's the Color Purple; A Paradox of the Divine

Alice Walker's Naturalistic Outlook of Religion

Theologians argue that women in general and black women in particular are more religious than men because of their experience with oppression. Rahiel Tesfamariam (2012) support the idea saying that, “ ... black women can bury bullet-filled sons, accept collect calls from imprisoned lovers and medicate HIV-infected bodies and still hold claim that God is not only real, but that God loves unconditionally. Through faith, we find the power to stop asking why and how." Further, Tesfamariam adds that faith to God enable African Americans to be connected with their ancestor. Being immigrants who had to fight with their complex identity reconciliation, faith to God leads to the sense of belonging. The exceptionality of women's vision of religiousness is well explained by Wirba Ibrahim (2002, p. 1) saying that:

\footnotetext{
Women's vision of religious issues is unique and tends toward subverting the established order and unsettling fixed racist/sexist/ capitalist meanings. They debunk traditional religious beliefs through a language that is frank, stripped of euphemisms and abstract symbolisms and attain spiritual individualism that [is] pregnant with potential.
}

Ibrahim's statement was my starting point to investigate further and deeper about uniqueness feature of religion in The Color Purple. Attention to religious discussion within African American communities typically held reductionist assumptions that African descendants in America are all theists. In fact, there are substantial historical and cultural evidence to suggest that many Black Americans stands on a wide-ranging standpoint towards religion. One particular standpoint that I would like to specify is religious humanism. Examples of humanism as life orientation, as religious system, are found throughout Black American culture, from slavery period to date. And perhaps the most forceful and clearly presented presentation of humanism as religion is found in the literature produced during the Harlem Renaissance onwards.

Explaining black female writers' perspective on religion, Ibrahim (2002: p. 5) observes that Alice Walker stands a particular humanist standpoint towards religiosity that makes her a prolific writer. She expresses a vision of religious issues that is humanist and committed to spiritual survival and 


\section{EduLite}

Journal of English Education, Literature, and Culture

Volume 1, Number 2, August 2016

wholeness of entire peoples. She proffers “... a vision in which women can attain spiritual self-fulfillment within the patriarchal order. By working ceaselessly to change the basic system of logic, which governs the patriarchal orthodoxy, she has opened up black women to spiritual possibilities that have hitherto been absent." The self-proclaimed human rights activist who is a staunch defender of rights of all living being is widely known for her concern for the black community.

Alice Walker's naturalistic humanism thoughts are reflected in many of the characters she created in her works. Celie and Shug Avery of The Color Purple might provide us insights into how Walker voices her liberative thoughts. Quoted by Anthony Pinn (in De La Torre, 2008, p. 64), she writes "I create characters who are not passive but active in the discovery of what us vital in this world ... who explore what it would feel like not to be imprisoned by hatred of women, the love of violence, destructiveness of greed taught to human beings as the 'religion' by which they must guide their lives." In this regard, Alice Walker acknowledges naturalistic humanism's potential as an active agent to recognize, cope, and address multilayered of oppression. Walker pinpoints spiritual self-fulfillment as a crucial medium that will enable (black) women to change society's system of logic. Unlike other women writers counterparts who believe that that patriarchy is irredeemable and women have no choice but to set up an alternative separate female culture (Preston, 1997, p. 4), Alice Walker stands on the opposite; she believes that if women are spiritually fulfilled, they will be able to challange the society's conception of women and their position in a patriarchal world order. This concept of spirituality is reflected in an interview with Claudia Tate (Ibrahim, 2002, p.6):

I've been trying to rid myself of the whole notion of God as a white haired, British man with big feet and beard. As a subjugated people, that image has almost been imprinted on our minds. It's there because of the whole concept of God as a person. Because if God he has to look like someone. But what I've been replacing that original oppressive image with every thing there is; so you get the desert, the trees, the birds, the dirt, everything.

Engaged in a long spiritual jouney, Alice Walker came to conceptualize (and re-conceptualize) her vision of God from a man-like being to natural being 
Yusak, God in Alice Walker's the Color Purple; A Paradox of the Divine

who is a non-sexist, non oppressive as well as non repressive. A form that, to her, is ideal. She explains on On The Issue (OTI) online (1997): "In day-to-day life, I worship the Earth as God representing everything and Nature as its spirit ... when someone you trust shows you a picture of a blond, blue-eyed Jesus Christ and tells you he's the son of God, you get an instant image of his father: an older version of him." Her disappointed to the hypocrisy-driven prescribed God is shown as she continues, “... when you're taught that God loves you, but only if you're good and so forth and you know you're that way only some of the time, there's a tendency to deny your shadow side. Hence the hypocrisy I noted early on in our church. The church I attended as a child still stands." Experience of discrimination and hypocrisy in the church who is very dear to her spirituality and childhood brings Walker to quest beyond finding a just God for her, but to humanity in general. Dissatisfied with the human-like God, her turning point to understand the divine from a naturalist perspective enables her to perceive God in a broader and more genuine sense.

God and the Paradox of Divinity in The Color Purple

Spirituality in African American history has always been a journey of searching, or a strive as Du Bois (Das Gupta, 2007, p. 144) put it, "The history of the American Negro is the history of this strive - this attain to selfconsciousness manhood, to merge his double self into a better and truer self." Written in an intimate epistolary form, Walker introduces the story by taking reader to live the abusive teen life of a 14-year-old Celie who lives a day-to-day life of sexual exploitation, physical violence and indoctrination of male domination in a patriarchal household. Helpless, confused and scared, Celie writes a series a journal of letters to God expressing her despair and hope to God. Analyzing the manner in writing journal; in a letterform and using vernacular English, Celie keeps her relation to her God honest and personal.

Celie grows a belief that God is an absolute patriarch. Her conception of God reflects her vision to men's patriarchy and absoluteness. Celie describes God as "... big and old and tall and grey-bearded and white" (Walker, 1998, p. 36). In her other description “... God coming down by chariot, swinging down real low and carrying ole Sofia home. I see 'em $\square$ all as clear as day. Angels all 


\section{EduLite}

Journal of English Education, Literature, and Culture

Volume 1, Number 2, August 2016

in white, white hair and white eyes, look like albinos. God all white too, looking like some stoutwhite man work at the bank" (Walker, 1998, p. 95). In some of Celie's letters, $\mathrm{Pa}$ is referred to as the capitalized "He" which normally used in reference to the God. Celie says, "Man corrupt everything . . . soon as you think he everywhere, you think he God" (Walker, 1998, p. 68). This conception is very likely to transpire when a young girl is growing up with a male figure who gives none other than distress. Broadly speaking, black family holds a very strong patriarchal structure where men leads and takes decisions. Having her Pa setting up rules on her over the time, Celie's perception builds up into an acceptance that black men are like gods, they govern women's lives and moreover decide their life and destiny.

As the story develops, Celie's perception of God becomes much more problematic. The once God-fearing girl has grown a stern faith that just like human, God is also complex deity holding multifold characteristics, including the merciless:

\footnotetext{
"What God do for me?" I ast.

She says, "Celie!" Like she shock. "He gave you life, good health, and a good woman that love you to death".

"Yeah", I say, "and he give me a lynched daddy, a crazy mama, a lowdown dog of a step pa and a sister I probably won't ever see again". "Anyhow", I say, "he God I been praying and writing to is a man. And act just tike all the other mens I know. Trifling, forgitful $\square$ and lowdown" (Walker, 1998, p. 199).
}

Up to this point, I infer that Celie's environment builds her early concept of God as absolute, patriarchal and human like. Celie's early concept of God was similar to Alice Walker's who once also thinks that God is human like - posess the feature of human being; with big feet and beard as Ibrahim reported (2002, p.6): "I've been trying to rid myself of the whole notion of God as a white haired, British man with big feet and beard. As a subjugated people, that image has almost been imprinted on our minds. It's there because of the whole concept of God as a person." Consequently, God own all human characteristics: prejudiced, dominant, self centered and even immoral. If so, does such God deserve a soul's love? Alice Walker insisted that God's love must be unconditional for His love to be fair to humanity. In summary she 
Yusak, God in Alice Walker's the Color Purple; A Paradox of the Divine

said: "A God specifically created to comfort, lead, advise, strengthen, and enlarge the tribal borders of someone else. We have been beggars at the table of a religion that sanctioned our destruction. All people deserve to worship a God who also worships them ... and it is fatal to love God who doesn't love you" (Walker, 1997). According to Walker, when one is taught a doctrine that God will love him but only if he is good, obedient, and trusting, this presents nothing but God's face whose love is conditional and there is a tendency of reprobation.

A conceptual turning point takes place when Shug Avery started to get involved in Celie's innate concept of God. Portrayed as an original, a liberated kind of black woman in this novel, Shrug is engaged in a series of thoughtful conversations with Celie. Contrasting her concept of God to Celie's, Shug believes that although Christianity may condemn her lifestyle and liberal worldview; God himself will not because $\mathrm{He}$ is kind and $\mathrm{He}$ is everything. Furthermore, Shug rejects Celie's patriarchal God as she presents her rather naturalist spirituality in perceiving God when she said: ""My first step from the old white man was trees. Then air. Then birds. Then other People. But one day when I was sitting quiet and feeling like a motherless child, which I was, it came to me: that feeling of being part of everything, not separate at all. God love all them feelings" (Walker, 1998, p.167). According to her interpretation, Celie's attempts to see God as a constitute patriarchy will only sustain men domination and suppression over women. Shug Avery strongly asserts that, 'He [man] try to make you think $\mathrm{He}$ everywhere. Soon as you think $\mathrm{He}$ everywhere you think he God. But He ain't. Whenever you try to pray and man plop himself on the other end of it, tell him to git lost' (Walker, 1998, p. 136). Surely, Shug Avery's lifestyle and liberal worldview developed her unconventional attitude of opposition towards patriarchal system - hence, her opposition to Celie's conception of God as an absolute patriarch. Perceiving God as a male figure not only distance Shrug to God, it accelerates male dominancy to a higher level. Shug's God is therefore, like the nature for anyone can feel 'It' because 'It' is everywhere just like the air, wind, trees, and birds. 
"Here's the thing", say Shug. "The thing I believe. God is inside you and inside everybody else. You come into the world with God. $\square$ But only them that search for it inside find it".

"It?" I ast.

"Yeah, It. God ain't a he or a she, but a It."

"But what do it look like?" I ast.

"Don't look like nothing", she say. "It ain't a picture show. It ain't something you can look at apart from anything else, including yourself. I believe God is everything", say Shug. "Everything that is or ever was or ever will be. And when you can feel that, and be happy to feel that, you've found It" (Walker, 1998, p. 202-3).

Shug expands her naturalist view as she explains: “... first step from the old white man was trees. Then air. Then birds. ... that feeling of being part of everything, not separate $\square$ at all. I knew that if I cut a tree, my arm would bleed. And I laughed and I cried and I run all around the house. I knew just $\square$ what it was.” (Walker, 1998, p. 203). This strong naturalist conception of God-man relation is approved by Alice Walker (2007) saying that, “... all people deserve to worship a God who also worships them. A God that made them, and likes them. That is why Nature, Mother Earth, is such a good choice. Never will Nature require that you cut off some part of your body to please her." Shug's naturalist conception of God turns to be a pivotal point in Celie's life. Her whole-hearted subscription to Shug's naturalist vision of the world and God affects a tremendous degree of autonomy and self-assertiveness in her. Finally, in last part of her letter, Celie addresses her letter to "Dear God. Dear stars, dear trees, dear skys, dear peoples, Dear Everything. Dear God." (Walker, 1998, p. 292). This salutation signifies her newly born conceptualization of God. Her acceptance to a more naturalist God is critical in Celie's life as it transforms her understanding of Black theology and society in general. Resting her fullest submission to the naturalist God allows Celie to believes that 'He' is no longer patriarchal nor dominant because just like the love of nature, God's love is and should be liberating.

\section{CONCLUSION}

In The Color Purple, theological transformation in the main characters' conception of God - from manlike to a more naturalist form - is closely 
Yusak, God in Alice Walker's the Color Purple; A Paradox of the Divine

intertwined with Alice Walker's naturalist conception of God. Alice Walker's spiritual journey was portrayed in Celie's early concept of God who is manlike; white man with beard and big feet. Shug Avery's conception of God (later followed by Celie) is a representation of Walker's later conception of God; that God does not take human characteristics. Rather, He is of natural being who surrounds us just like the nature. In order to understand God better, one needs to be united with the universe and becomes a part of it. In addition, Alice Walker's past experience of hypocrisy and disappointment in her community church has led her tendency towards religious naturalism. Apart from the discussion on what an ideal concept of God is, I am finally convinced to highlight Celie's effort who decided to believe that instead of being defined by others, truth is to be self-discovered.

\section{REFERENCES}

Anyabwile, Thabiti. (2007). The Decline of African American Theology: From Biblical Faith to Cultural Captivity. Illinois, USA: Intervarsity Press.

Du Bois, William Edward Burkhart. (2007). "Of Our Spiritual Striving" in Tania Das Gupta et al. (Ed), Race and Racialization; Essential Readings, p. 144-148. Ontario, Toronto: Marquis Book Printing.

Erickson, Gregory. (2000) The Absence of God in Modernist Literature. New York, USA: Palgrave Macmillan, 2007. Illinois, USA: University of Illinois Press.

Gates, Henry Louis Jr., and K.A. Appiah. (1993). Alice Walker. New York: Amistad Press.

Hine, Darlene Clark. (1997). Black Women in America; Religion and Community. New York: Facts On File, Inc.

Hoffman, Frederick. (1951). The Modern Novel in America; 1900-1950. Chicago: Henry Regnery Co.

Labbé-DeBose, Theola. (2012). Black Women are among Country's most Religious Groups. The Washington Post. Retrieved from http://www.washingtonpost.com/ on December 16, 2013.

McKever Floyd, Preston. (2007, Fall). 'Tell Nobody but God: the Theme of Transformation in The Color Purple'. Cross Currents. 
Miller, Hillis. (2000). The Disappearance of God: Five Nineteenth-Century Writers. MA: Harvard University Press.

Pinn, Anthony. (2009). African American Religious Cultures. California: ABCCLIO, LLC.

Stone, Jerome. (2008). Religious Naturalism Today; Rebirth of a Forgotten Alternative. New York: State University of New York Press.

Tesfamariam, Rahiel. (2012, July 13). The Importance of God in our Lives as Black Women. Washington Post. Retrieved from http://www.washingtonpost.com/ on December 16, 2013.

Walker, Alice. (1998). The Color Purple. New York: Pocket Books.

Walker, Alice. (1997, Spring). "The Only Reason You Want to Go to Heaven is That You Have Been Driven Out of Your Mind" in On the Issues Magazine. $\quad$ Spring $1997 . \quad$ Retrieved from http://www.ontheissuesmagazine.com/1997spring on 29 January 2015.

Wirba Ibrahim, Mainimo. (2002, Spring). 'Black Female Writers' Perspective on Religion: Alice Walker and Calixthe Beyala'. Journal of Third World Studies. 